\title{
Risiko Keuangan, Dewan Komisaris, Dewan Direksi dan Kinerja Keuangan Bank Perkreditan Rakyat
}

\author{
Ni Putu Pradina Mas Jaya Ningrum ${ }^{*}$ \\ Ni Ketut Rasmini2 ${ }^{2}$ \\ 1,2Fakultas Ekonomi dan Bisnis Universitas Udayana, Indonesia \\ *Correspondences: madinapradina@gmail.com
}

\begin{abstract}
ABSTRAK
Tujuan penelitian ini adalah untuk memperoleh bukti empiris pengaruh risiko keuangan, dewan komisaris, dan dewan direksi pada kinerja keuangan BPR. Penelitian ini dilakukan di Bank Perkreditan Rakyat (BPR) Kabupaten Badung. Metode penentuan sampel yang digunakan adalah purposive sampling. Jumlah sampel yang diambil sebanyak 31 BPR dengan pengamatan 2 tahun sehingga terdapat 62 amatan. Teknik analisis yang dilakukan adalah regresi linear berganda. Berdasarkan hasil analisis ditemukan bahwa risiko kredit, risiko likuiditas, dan risiko operasional berpengaruh negatif terhadap kinerja keuangan, sedangkan dewan komisaris dan dewan direksi berpengaruh positif terhadap kinerja keuangan. Hal ini menunjukkan bahwa semakin meningkat risiko kredit, risiko likuiditas, risiko operasional maka akan menurunkan kinerja keuangan sedangkan semakin banyaknya jumlah dewan komisaris dan dewan direksi maka semakin banyak juga yang mengontrol dan mengawasi perusahaan dalam memenuhi kinerja keuangan.
\end{abstract}

Kata Kunci: Kinerja Keuangan; Risiko Keuangan; Dewan Komisaris; Dewan Direksi, BPR.

\section{Financial Risk, Board of Commissioners, Board of Directors and Financial Performance of Rural Banks}

\begin{abstract}
The purpose of this study was to obtain empirical evidence of the effect of financial risk, the board of commissioners, and the board of directors on the financial performance of rural banks. This research was conducted at the Rural Bank (BPR) Badung Regency. The method of determining the sample used is purposive sampling. The number of samples taken was 31 BPRs with 2 years of observation so that there were 62 observations. The analysis technique used is multiple linear regression. Based on the results of the analysis, it was found that credit risk, liquidity risk, and operational risk have a negative effect on financial performance, while the board of commissioners and the board of directors have a positive effect on financial performance. This shows that the increasing credit risk, liquidity risk, and operational risk will reduce financial performance, while the greater the number of the board of commissioners and the board of directors, the more will control and supervise the company in meeting financial performance.
\end{abstract}

Keywords: Financial Performance; Financial Risk; Board of Commissioners; Board of Directors, BPR.

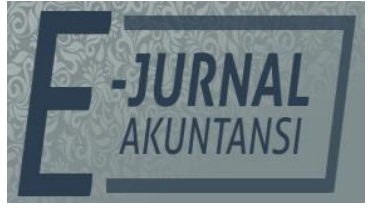

e-ISSN 2302-8556

Vol. 32 No. 1

Denpasar, Januari 2022

Hal. 109-123

DOI:

10.24843/EJA.2022.v32.i01.p08

PENGUTIPAN:

Ningrum, N. P. P. M. J. \& Rasmini, N. K. (2022). Risiko Keuangan, Dewan Komisaris, Dewan Direksi dan Kinerja Keuangan Bank Perkreditan Rakyat. E-Jurnal Akuntansi, 32(01), 109-123

RIWAYAT ARTIKEL: Artikel Masuk: 17 Maret 2021 Artikel Diterima: 12 Agustus 2021

Artikel dapat diakses : https://ojs.unud.ac.id/index.php/Akuntansi/index 


\section{PENDAHULUAN}

Kinerja BPR di Provinsi Bali terus meningkat dan menunjukan pertumbuhan yang positif. Penyaluran kredit oleh BPR di Bali pada tahun 2019 tercatat sebesar Rp11,16 triliun (10,28\%), meningkat dari periode sebelumnya yang tumbuh 6,66\%. Penyaluran kredit paling banyak untuk membiayai sektor perdagangan besar dan eceran yaitu sebesar Rp3,2 triliun (28,72\% dari total kredit) dan real estate sebesar Rp1,4 triliun (12,6\% dari total kredit).

Komposisi penyaluran kredit BPR di Bali didominasi oleh kredit produktif yaitu sebesar 62,76\% (Rp7 triliun), yang terdiri dari Kredit Modal Kerja sebesar Rp5,3 triliun dan kredit investasi sebesar Rp1,7 triliun. Rasio non performing loan (NPL) BPR di Bali sebesar 8,28\% di bulan September 2019, sedangkan return on assets (ROA) menurun dari 2,17\% menjadi 1,75\% dan rasio BOPO meningkat dari 79,94\% menjadi 82,94\% (Agustini, 2019). Dari 137 BPR yang ada di provinsi Bali, hanya terdapat tiga BPR yang bermasalah yaitu satu di Kota Denpasar dan dua di Kabupaten Badung.

Otoritas Jasa Keuangan (OJK) mencabut izin usaha PT Bank Perkreditan Rakyat KS Bali Agung Sedana, BPR tersebut telah masuk status Bank Dalam Pengawasan Khusus sejak 12 April 2017. Penetapan status Bank Dalam Pengawasan Khusus disebabkan kesalahan pengelolaan oleh manajemen BPR yang mengakibatkan kinerja keuangan BPR tidak dapat memenuhi standar yang ditetapkan (www.republika.co.id diakses tanggal 20 Februari 2020). Pada tanggal 13 Agustus 2019 pencabutan izin usaha kembali terjadi pada PT Bank Perkreditan Rakyat Calliste Bestari. Penyebab BPR Callieste bermasalah karena adanya praktek perbankan yang tidak sehat baik oleh Pengurus maupun Pemegang Saham sehingga kinerja keuangan BPR menjadi buruk terutama rasio Kewajiban Penyediaan Modal Minimum tidak memenuhi standar yang ditetapkan sesuai ketentuan yang berlaku paling sedikit $8 \%$. Hal ini terjadi karena pemberian kredit yang tidak sehat dengan menggunakan beberapa nama debitur, namun sebenarnya dana hasil kredit digunakan untuk kepentingan pribadi pemegang saham pengendali atau sering disebut dengan kredit topengan (bali.tribunnews.com diakses tanggal 20 Februari 2020).

Lembaga keuangan diharapkan melakukan efisiensi operasi, yaitu untuk mengetahui apakah lembaga keuangan dalam operasinya yang berhubungan dengan usaha pokok lembaga keuangan, dilakukan dengan benar dalam artian sesuai yang diharapkan manajemen (Hanley, 1997). Perusahaan akan menghadapi risiko dan tantangan yang semakin sering akan terjadi. Risiko dan tantangan ini dapat terjadi dikarenakan perusahaan ingin mencapai tujuan yang telah ditetapkan, salah satunya mencapai laba maksimal (Ariestya \& Ardiana, 2016). Berdasarkan surat edaran otoritas jasa keuangan nomor 1/SEOJK.03/2019 penerapan manajemen risiko untuk masing-masing jenis risiko, meliputi penerapan manajemen risiko untuk keseluruhan jenis risiko, yaitu risiko kredit, risiko operasional, risiko kepatuhan, risiko likuiditas, risiko reputasi, dan risiko stratejik, dengan tetap mengacu kepada jenis risiko yang wajib dikelola oleh masing-masing BPR berdasarkan modal inti, total aset, jaringan kantor, dan kegiatan usaha yang dilakukan BPR. Risiko kredit, risiko likuiditas, dan risiko operasional merupakan beberapa risiko yang sering dihadapi institusi perbankan. 
Berdasarkan data atau informasi yang diperlukan, risiko dapat dibedakan menjadi dua, yaitu risiko yang dapat dilihat dari informasi keuangan atau risiko spekulatif dan risiko yang dapat dilihat dari informasi lainnya diluar laporan keuangan. Risiko yang dapat dilihat melalui informasi lainnya diluar dari laporan keuangan adalah risiko pasar, risiko hukum, risiko reputasi, risiko stratejik, dan risiko kepatuhan sedangkan risiko yang dapat dinilai melalui data laporan keuangan atau risiko spekulatif meliputi risiko kredit, risiko operasional, dan risiko likuiditas.

Kondisi kinerja keuangan perbankan saat ini belumlah konstan. Kondisi internal bank yang lemah seperti manajeman yang kurang baik dapat menyebabkan kinerja keuangan bank menurun. Kinerja keuangan bank dapat dipengaruhi oleh beberapa faktor diantaranya adalah risiko kredit, risiko likuiditas dan risiko operasional. Faktor pertama yang mempengaruhi kinerja keuangan yaitu risiko kredit. Risiko kredit adalah risiko kerugian bagi bank karena debitur tidak dapat melunasi kembali pokok pinjaman beserta bunganya (Cahyaningtyas \& Sasanti, 2019). Berdasarkan penelitian Hanafi (2016), risiko kredit terjadi jika counterparty (pihak lain dalam transaksi bisnis kita) tidak bisa memenuhi kewajibannya (wanprestasi). Risiko kredit berasal dari kegiatan penyaluran dana dan komitmen lain, risiko ini timbul karena pihak peminjam tidak dapat memenuhi kewajiban finansialnya kepada bank pada saat jatuh tempo. Pada penelitian ini risiko kredit diukur dengan Non Performing Loan (NPL). Semakin tinggi NPL berarti risiko kredit yang dimiliki oleh bank juga semakin tinggi.

Berdasarkan penelitian Saputra \& Permana (2020) dan Ismanto (2020) menunjukan bahwa risiko kredit berpengaruh negatif pada kinerja keuangan, tetapi penelitian yang dilakukan oleh Jha \& Xiaofeng (2012) menemukan hasil bahwa risiko kredit memiliki pengaruh positif pada kinerja keuangan.

Faktor kedua yang mempengaruhi kinerja keuangan yaitu risiko likuiditas. Risiko likuiditas adalah kewajiban yang harus dibayar oleh Perusahaan pada tanggal jatuh tempo. Ini berarti bahwa perusahaan dalam keadaan likuid jika perusahaan memiliki aset jangka pendek yang melebihi utang jangka pendeknya. Indikator untuk mengukur risiko likuiditas adalah penggunaan rasio deposit terhadap deposito (LDR), yang merupakan rasio pinjaman pihak ketiga terhadap dana pihak ketiga (Erawati \& Teguh, 2020). Hal ini menandakan adanya pengaruh seperti yang dibuktikan oleh Sandy (2015) dan Korompis et al., (2020) bahwa LDR berpengaruh negatif terhadap kinerja keuangan perbankan.

Risiko Operasional merupakan risiko yang disebabkan oleh kurang berfungsinya proses internal bank, humam error, kegagalan sistem teknologi, atau akibat permasalahan eksternal (Attar \& Shabri, 2014). Indikator yang digunakan untuk mengukur risiko operasional adalah menggunakan rasio Beban Operasioanal terhadap Pendapatan Operasional (BOPO). Rasio BOPO digunakan untuk mengukur kemampuan manajemen bank dalam mengendalikan biaya operasional terhadap pendapatan operasional (Nurintan, 2016). BOPO yang tinggi menunjukan tingkat efisiensi yang rendah dari bank dalam menjalankan usahanya sehingga menyebabkan kerugian. Penelitian Santosa (2019) dan Ismanto (2020) menunjukan hasil bahwa risiko operasional berpengaruh negatif terhadap kinerja keuangan. 
Bank Pekreditan Rakyat (BPR) juga menjadi salah satu contoh perusahaan yang mengimplementasikan GCG. Otoritas Jasa Keuangan (OJK) telah menerbitkan peraturan nomor 4/POJK.03/2015 tentang Penerapan Tata Kelola bagi Bank Perkreditan Rakyat (BPR). BPR diwajibkan membuat laporan pelaksanaan tata kelola perusahaan setiap tahun kepada OJK. BPR harus segera mengimplementasikan peraturan tata kelola pada semua kegiatan dan seluruh tingkatan organisasi. Penerapan GCG sangat diperlukan oleh semua entitas bisnis. Perusahaan atau entitas bisnis wajib menerapkan praktik GCG. Hal ini diperkuat dengan terbitnya pedoman umum GCG oleh Komite Nasional Kebijakan Governance (KNKG) yang mewajibkan setiap entitas bisnis untuk menerapkan praktik GCG. Penerapan GCG dalam kinerja perusahaan merupakan kunci sukses bagi perusahaan untuk memperoleh keuntungan dalam jangka panjang dan dapat bersaing dengan baik dalam bisnis global. Hasil survey yang dilakukan oleh McKinsey \& Co. (2020) mengatakan bahwa para investor cenderung menghindari perusahaan-perusahaan dengan predikat buruk dalam Corporate Governance. Perhatian yang diberikan investor terhadap GCG sama besarnya dengan perhatian terhadap kinerja keuangan perusahaan.

Kebutuhan GCG timbul berkaitan dengan principal- agency theory, yaitu untuk menghindari konflik antara prinsipal dan agent. (Hart, 1995) menyatakan bahwa Corporate Governance muncul dalam organisasi disebabkan karena adanya masalah agensi atau konflik kepentingan yang melibatkan anggota organisasi. Konflik muncul karena perbedaan kepentingan tersebut haruslah dikelola sehingga tidak menimbulkan kerugian pada para pihak, dengan adanya GCG tentunya dapat menjadi alat untuk memotivasi manajer agar mampu memaksimalkan nilai pemegang saham (Hamdani, 2016). GCG sangatlah penting dan merupakan kebutuhan yang harus dipenuhi dan dijalankan agar kelangsungan hidup suatu perusahaan dapat berjalan dengan baik. Dengan menerapkan prinsip tata kelola perusahaan (GCG) dalam mekanisme perusahaan akan meningkatkan nilai perusahaan yang akan berpengaruh terhadap kelangsungan hidup dan kinerja perusahaan (Muryati \& Suardikha, 2014). Penerapan GCG menunjukan betapa pentingnya dalam mendukung tercapainya tujuan perusahaan dan dasar dari pengambilan kebijakan-kebijakan perusahaan sehingga memberikan keuntungan kepada berbagai pihak yang berkepentingan (stakeholder). Penerapan GCG juga mampu membantu perusahaan untuk mengelola dengan baik kinerja keuangan suatu perusahaan agar mencapai tujuan keberhasilan dari segala aktivitas-aktivitas yang sudah dilalui selama satu periode.

Menurut Pontoh et al. (2013:164) dalam (Anggriani, 2017) Corporate Governance adalah serangkaian mekanisme yang dapat melindungi pihak-pihak minoritas (outside investors/minority shareholders) dari ekspropriasi yang dilakukan para manajer dan pemegang saham pengendali dengan penekanan pada mekanisme legal. Mekanisme dalam pengawasan Corporate Governance dibagi dalam dua kelompok yaitu mekanisme internal dan eksternal. Mekanisme internal adalah cara untuk mengendalikan perusahaan menggunakan struktur dan proses internal seperti rapat umum pemegang saham (RUPS), komposisi dewan direksi, komposisi dewan komisaris dan pertemuan dengan board of director sedangkan mekanisme eksternal adalah cara mempengaruhi perusahaan selain dengan 
menggunakan mekanisme internal, seperti pengendalian oleh perusahaan dan pengendalian pasar (Anggriani, 2017).

Dewan komisaris, komisaris independen, dan komite audit merupakan mekanisme pengawasan GCG. Struktur BPR di bali terdiri dari dewan komisaris, dewan direksi, dan shareholder, sehingga mekanisme GCG pada penelitian ini diproksikan dengan dewan komisaris dan dewan direksi. Dewan komisaris memiliki peranan penting dalam mengarahkan strategi dan mengawasi jalannya perusahaan, serta memastikan bahwa para manajer benar-benar meningkatkan kinerja perusahaan, sehingga tujuan perusahaan bisa tercapai. Dalam mewakili perusahaan, dewan direksi memili hak dalam urusan di luar perusahaan maupun didalam perusahaan. Berdasarkan penelitian yang dilakukan oleh Julastri \& Dewi (2018)menyatakan bahwa ukuran dewan direksi memiliki pengaruh yang signifikan positif terhadap kinerja perusahaan. Hal ini dapat terjadi karena semakin banyaknya jumlah dewan direksi maka semakin banyak juga yang mengontrol dan mengawasi perusahaan dalam memenuhi kinerja perusahaan.

(Fitri, 2016), dalam penelitiannya risiko kredit yang diukur dengan NPL (Net Performing Loan) menunjukan bahwa penerapan risiko kredit (NPL) berpengaruh negatif signifikan terhadap kinerja keuangan.(Bastomi et al., 2017) menyatakan bahwa risiko kredit berpengaruh negatif terhadap kinerja keuangan.

Risiko kredit dapat diukur menggunakan Non Performing Loan (NPL). NPL merupakan perbandingan antara total kredit bermasalah dengan total kedit yang diberikan kepada debitur, semakin kecil NPL maka bank dapat mengelola risiko kreditnya dengan baik sehingga dapat berdampak baik pada penilaian kinerja keuangan bank. Hal ini sesuai juga dengan teori sinyal (signalling theory) dimana sinyal yang baik akan berpengaruh baik terhadap pasar. Nilai NPL yang rendah mencerminkan sinyal yang baik sehingga dapat berpengaruh meningkatkan rating bank.

$\mathrm{H}_{1}$ : Risiko kredit berpengaruh negatif pada kinerja keuangan BPR di Kabupaten Badung.

LDR adalah rasio dari jumlah total pinjaman bank terhadap dana yang diterima dari bank (Anam \& Handayani, 2018). Semakin tinggi LDR, semakin tinggi dana yang ditransfer ke dana pihak ketiga. Dengan penyaluran dana pihak ketiga yang besar maka bank akan memperoleh kinerja (ROA) yang semakin meningkat. Karena semakin besar utang bank maka semakin menurun kinerja keuangan bank. Hal ini juga sesuai dengan teori sinyal (Signalling Theory) yang menyatakan bahwa sinyal yang baik akan berpengaruh baik terhadap pasar. LDR yang tinggi mencerminkan sinyal yang baik karena menggambarkan tingkat likuiditas yang bagus, sehingga dapat meningkatkan rating bank. Berdasarkan hasil penelitian Gyan Exqyu Sandy (2015) dan Wibowo (2020) yang menyatakan bahwa LDR berpengaruh negatif terhadap kinerja keuangan perbankan.

$\mathrm{H}_{2}$ : Risiko Likuiditas berpengaruh negatif pada kinerja keuangan BPR di Kabupaten Badung.

Berdasarkan hasil penelitian Wirawan \& Putri (2018) yang menyatakan bahwa Manajemen Risiko berpengaruh negatif pada kinerja keuangan koperasi di Kabupaten Gianyar. Berdasarkan data BOPO koperasi di Kabupaten Gianyar periode 2013-2015 bahwa rasio BOPO rata-rata dibawah 90\%. Hal ini dapat diartikan bahwa koperasi yang ada di Kabupaten Gianyar sudah efisien dalam 
melaksanakan kegiatannya. Penelitian ini sejalan dengan penelitian Ismanto (2020) yang menyatakan risiko operasional berpengaruh negatif pada kinerja keuangan.

$\mathrm{H}_{3}$ : Risiko Operasional berpengaruh negatif pada kinerja keuangan BPR.

Dewan komisaris memiliki andil yang sangat besar dalam pelaksanaan GCG. Jika fungsi dewan komisaris sudah berjalan efektif maka sistem pengawasan di perusahaan tersebut semakin baik serta dapat menjamin kesuksesan pelaksanaan GCG, dan pada akhirnya akan berdampak positif pada kinerja keuangan. Teori agensi menyatakan dewan komisaris merupakan mekanisme pengendalian intern tertinggi yang bertanggung jawab untuk memonitor segala tindakan manajer dalam mengelola perusahaan. Berdasarkan hasil penelitian Sulistyowati \& Fidiana (2017) yang menyatakan bahwa ukuran dewan komisaris yang dilihat dari jumlah dewan komisaris berpengaruh positif pada kinerjaa keuangan.

$\mathrm{H}_{4}$ : Dewan Komisaris berpengaruh positif pada kinerja keuangan BPR di Kabupaten Badung.

Deskripsi bahwa manajer adalah agen bagi para pemegang saham atau dewan direksi adalah benar sesuai dengan teori keagenan. Dewan direksi merupakan pihak dalam suatu entitas perusahaan yang bertugas melakukan dan melaksanakan operasi dan kepengurusan perusahaan. Dewan direksi bertanggung jawab penuh atas segala bentuk operasional dan kepengurusan perusahaan dalam rangka melaksanakan kepentingan-kepentingan dalam pencapaian tujuan perusahaan. Direksi pada dasarnya memiliki hak pengendalian yang siginifikan dalam pengelolaan sumber daya perusahaan dan dana dari investor (Sukandar, 2014). Semakin meningkatnya jumlah dewan direksi, maka akan semakin banyak yang melakukan pengawasan terhadap pengelolaan sumber daya perusahaan. Berdasarkan hasil penelitian Meirina \& Abaharis (2019) yang menyatakan bahwa dewan direksi berpengaruh positif dan signifikan pada kinerja keuangan perbankan. Penelitian terdahulu yang dilakukan oleh Laksana (2015) menunjukkan bahwa semakin besar jumlah dewan direksi dalam perusahaan maka koordinasi dan komunikasi akan cenderung lebih mudah dilakukan, sehingga kinerja keuangan perusahaan akan semakin meningkat.

$\mathrm{H}_{5}$ : Dewan Direksi berpengaruh positif pada kinerja keuangan BPR di Kabupaten Badung.

\section{METODE PENELITIAN}

Penelitian ini dilakukan pada seluruh BPR di Kabupaten Badung. Adapun alasan peneliti melakukan penelitian pada BPR Kabupaten Badung yaitu adanya dua BPR yang masuk kedalam status bank dalam pengawasan khusus hingga dicabutnya izin usaha BPR tersebut.

ROA digunakan untuk mengukur efektifitas perusahaan didalam menghasilkan keuntungan dengan memanfaatkan aktiva yang dimilikinya. ROA merupakan rasio antara laba yang diperoleh terhadap total asset. Semakin besar ROA menunjukkan kinerja keuangan yang semakin baik, karena tingkat kembalian (return) semakin besar. ROA dirumuskan sebagai berikut.

$R O A=\frac{\text { Laba }}{\text { Total aset }} \times 100 \%$ 
Risiko kredit merupakan risiko yang terjadi akibat ketidakmampuan suatu perusahaan dalam memenuhi kewajibannya tepat pada waktu yang telah disepakati. Risiko kredit dapat diukur menggunakan Non Performing Loan (NPL). NPL merupakan perbandingan antara total kredit bermasalah dengan total kedit yang diberikan kepada debitur.

$$
N P L=\frac{\text { Kredit bermasalah } / \text { macet }}{\text { Total kredit }} \times 100 \%
$$

Risiko likuiditas merupakan risiko yang dihadapi bank dalam menyediakan alat untuk memenuhi permintaan kredit dan semua penarikan dana yang disimpan oleh deposan pada waktu tertentu (Rahmi, 2014). Risiko ini dapat terjadi dikarenakan penyaluran dana dalam bentuk kredit lebih besar daripada deposit atau simpanan masyarakat pada suatu bank, sehingga menimbulkan resiko yang harus ditanggung oleh bank yaitu ketidakmampuan bank dalam memenuhi kebutuhan transaksi dan kewajiban bank dengan jatuh tempo tidak lebih atau kurang dari satu tahun. Risiko likuiditas dapat dinilai menggunakan Loan to Deposit Ratio (LDR). Adapun rumusnya sebagai berikut.

$$
L D R=\frac{\text { Total Kredit }}{\text { Total dana pihak ketiga }} \times 100 \%
$$

Risiko Keuangan bisa terjadi disetiap perusahaan. Risiko bisa menjadi penghambat dalam kelangsungan perusahaan. Risiko dalam penelitian ini diproksikan pada risiko operasional dalam BPR yang diukur menggunakan BOPO. Adapun rumus untuk mencari Beban Operasional Pendapatan Operasional (BOPO) adalah sebagai berikut.

$B O P O=\frac{\text { Total biaya operasional }}{\text { Total pendapatan operasional }} \times 100 \%$

Dewan komisaris merupakan organ perusahaan bertugas dan bertanggung jawab secara bersama-sama untuk melakukan pengawasan dan memberikan pendapat kepada Board of Directors serta memastikan bahwa perusahaan telah melaksanakan corporate governance. Dewan komisaris memiki wewenang dan bertanggung jawab memberikan pengarahan kepada manajemen dalam menyusun laporan keuangan perusahaan. Ukuran dewan komisaris diukur dengan menggunakan indikator jumlah anggota dewan komisaris suatu perusahaan. Berikut rumus Jumlah Dewan Komisaris.

Jumlah Dewan Komisaris $=\Sigma$ anggota dewan komisaris

Dewan direksi bertanggung jawab penuh atas segala bentuk operasional dan kepengurusan perusahaan dalam rangka melaksanakan kepentingankepentingan dalam pencapaian tujuan perusahaan. Direksi pada dasarnya memiliki hak pengendalian yang siginifikan dalam pengelolaan sumber daya perusahaan dan dana dari investor (Sukandar, 2014). Semakin meningkatnya jumlah dewan direksi, maka akan semakin banyak yang melakukan pengawasan terhadap pengelolaan sumber daya perusahaan. Berikut rumus Jumlah Dewan Direksi yaitu sebagai berikut.

Jumlah Dewan Direksi $=\Sigma$ anggota dewan direksi

Populasi dalam penelitian ini adalah seluruh BPR yang berada di Kabupaten Badung. Sampel dalam penelitian ini adalah BPR yang dipilih menggunakan teknik purposive sampling yang berada di kabupaten badung. Jumlah sampel pada penelitian ini adalah 62. Metode penentuan sampel yang digunakan dalam 
penelitian ini adalah dengan metode nonprobability sampling dengan teknik purposive sampling.

Teknik analisis data yang dipergunakan untuk memecahkan masalah dalam penelitian ini adalah teknik analisis linear berganda. Teknik analisis linear berganda digunakan untuk mengetahui ketergantungan suatu variabel terikat terhadap satu atau lebih variabel bebas dengan atau tanpa variabel moderator. Adapun model regresi linear berganda dengan menggunakan persamaan sebagai berikut ( Sugiyono, 2017:277)

$Y=a+\beta_{1} X_{1}+\beta_{2} X_{2}+\beta_{3} X_{3}+\beta_{4} X_{4}+\beta_{5} X_{5}+\varepsilon$

Keterangan:

$\begin{array}{ll}\mathrm{Y} & =\text { Variabel terikat (Kinerja Keuangan) } \\ \mathrm{a} & =\text { Konstanta } \\ \beta_{1}, \beta_{2}, \beta_{3}, \beta_{4}, \beta_{4} & =\text { Koefisien regresi } \\ \mathrm{X}_{1} & =\text { Risiko Kredit } \\ \mathrm{X}_{2} & =\text { Risiko Likuiditas } \\ \mathrm{X}_{3} & =\text { Risiko Operasional } \\ X_{4} & =\text { Dewan Komisaris } \\ X_{5} & =\text { Dewan Direksi } \\ \varepsilon & =\text { Standar Error }\end{array}$

\section{HASIL DAN PEMBAHASAN}

Statistik deskriptif digunakan untuk memberikan deskripsi variabel penelitian yang dilihat dari rata-rata (mean), standar deviasi (standard deviation), maksimum dan minimum. Secara rinci karakteristik disajikan pada Tabel 1.

Tabel 1. Analisis Statistik Deskriptif

\begin{tabular}{lccccc} 
& N & Minimum & Maximum & Mean & Std. Deviation \\
\hline Risiko Kredit & 62 & 0,00 & 34,41 & 10,391 & 8,410 \\
Risiko Likuiditas & 62 & 57,82 & 97,69 & 76,936 & 9,131 \\
Risiko Operasional & 62 & 50,19 & 143,22 & 88,426 & 14,703 \\
Dewan Komisaris & 62 & 2,00 & 2,50 & 2,008 & 0,063 \\
Dewan Direksi & 62 & 2,00 & 3,00 & 2,016 & 0,127 \\
Kinerja Keuangan & 62 & $-5,97$ & 17,41 & 2,126 & 3,166 \\
\hline
\end{tabular}

Sumber: Data Penelitian, 2021

Berdasarkan hasil analisis statistik deskriptif data pada Tabel 1, menunjukan hasil bahwa sampel yang berjumlah 62 dengan penjabaran risiko kredit memiliki nilai minimal 0,00. Nilai maksimal sebesar 34,41 dan rata - rata sebesar 10,391 dengan standar deviasi sebesar 8,410. Risiko likuiditas memiliki nilai minimal 57,82. Nilai maksimal sebesar 97,69 dan rata - rata sebesar 76,936 dengan standar deviasi sebesar 9,131. Risiko operasional memiliki nilai minimal 50,19 . Nilai maksimal sebesar 143,22 dan rata - rata sebesar 88,426 dengan standar deviasi sebesar 14,703. Dewan komisaris memiliki nilai minimal 2. Nilai maksimal sebesar 2,50 dan rata - rata sebesar 2,008 dengan standar deviasi sebesar 0,064. Dewan dereksi memiliki nilai minimal 2. Nilai maksimal sebesar 3 dan rata-rata sebesar 2,01 dengan standar deviasi sebesar 0,127. Kinerja Keuangan memiliki nilai minimal $-5,97$. Nilai maksimal sebesar 17,41 dan rata-rata sebesar 2,126 dengan standar deviasi sebesar 3,166. 
Teknik analisis data yang dipergunakan untuk memecahkan masalah dalam penelitian ini adalah teknik analisis linear berganda. Teknik analisis linear berganda digunakan untuk mengetahui ketergantungan suatu variabel terikat terhadap satu atau lebih variabel bebas dengan atau tanpa variabel moderator.

Tabel 2. Hasil Analisis Regresi Linier Berganda

\begin{tabular}{|c|c|c|c|c|c|}
\hline \multirow[b]{2}{*}{ Model } & \multicolumn{2}{|c|}{$\begin{array}{l}\text { Unstandardized } \\
\text { Coefficients }\end{array}$} & \multirow{2}{*}{$\begin{array}{c}\text { Standardized } \\
\text { Coefficients } \\
\text { Beta }\end{array}$} & \multirow[t]{2}{*}{$\mathrm{t}$} & \multirow[t]{2}{*}{ Sig. } \\
\hline & B & Std. Error & & & \\
\hline 1 (Constant) & 17,927 & 10,157 & & 1,765 & 0,000 \\
\hline Risiko Kredit & $-0,007$ & 0,037 & $-0,019$ & $-3,194$ & 0,000 \\
\hline Risiko Likuiditas & $-0,007$ & 0,032 & $-0,019$ & $-4,205$ & 0,000 \\
\hline Risiko Operasional & $-0,167$ & 0,021 & $-0,777$ & $-7,801$ & 0,000 \\
\hline Dewan Komisaris & 0,582 & 4,382 & 0,012 & 5,133 & 0,000 \\
\hline Dewan Direksi & 0,861 & 2,165 & 0,035 & 3,398 & 0,000 \\
\hline
\end{tabular}

Sumber: Data Penelitian, 2021

Berdasarkan hasil analisis regresi seperti yang disajikan pada Tabel 2, maka dapat dibuat persamaan regresi sebagai berikut.

$$
Y=17,927-0,007 X_{1}-0,007 X_{2}-0,167 X_{3}+0,582 X_{4}+0,861 X_{5}
$$

Nilai konstanta sebesar 17,927, artinya jika variabel risiko kredit, risiko likuiditas, risiko operasional, dewan komisaris dan dewan direksi bernilai 0 maka nilai kinerja keuangan sebesar 17,927. Nilai koefisien variabel risiko kredit $\left(X_{1}\right)$ bernilai $-0,007$, artinya apabila risiko kredit $\left(X_{1}\right)$ mengalami peningkatan satu satuan dengan asumsi variabel risiko likuiditas, risiko operasional, dewan komisaris dan dewan direksi dianggap tetap maka kinerja keuangan akan menurun sebesar 0,007. Nilai koefisien variabel risiko likuiditas $\left(X_{2}\right)$ bernilai - 0,007 , artinya apabila risiko likuiditas $\left(\mathrm{X}_{2}\right)$ mengalami peningkatan satu satuan dengan asumsi variabel risiko kredit, risiko operasional, dewan komisaris dan dewan direksi dianggap tetap maka kinerja keuangan akan menurun sebesar 0,007. Nilai koefisien variabel risiko operasional $\left(X_{3}\right)$ bernilai $-0,167$ artinya apabila risiko operasional $\left(X_{3}\right)$ mengalami peningkatan satu satuan dengan asumsi variable risiko kredit, risiko likuiditas, dewan komisaris dan dewan direksi dianggap tetap maka kinerja keuangan akan menurun sebesar 0,167. Nilai koefisien variabel dewan komisaris $\left(\mathrm{X}_{4}\right)$ bernilai 0,582 artinya apabila dewan komisaris $\left(\mathrm{X}_{4}\right)$ mengalami peningkatan satu satuan dengan asumsi variabel risiko kredit, risiko likuiditas, risiko operasional dan dewan direksi dianggap tetap maka kinerja keuangan akan meningkat sebesar 0,582 . Nilai koefisien variabel dewan direksi $\left(X_{5}\right)$ bernilai 0,861 artinya apabila dewan direksi $\left(X_{5}\right)$ mengalami peningkatan satu satuan dengan asumsi variabel risiko kredit, risiko likuiditas, risiko operasional dan dewan komisaris dianggap tetap maka kinerja keuangan akan meningkat sebesar 0,861.

Penelitian ini menggunakan koefisien determinasi nilai dari Adjusted $\mathrm{R}^{2}$ karena nilai Adjusted $\mathrm{R}^{2}$ dapat naik atau turun apabila variabel ditambahkan dalam model.

Tabel 3. Hasil Analisis Koefisien Deteminasi

\begin{tabular}{ccccc}
\hline Model & $\mathrm{R}$ & $\mathrm{R}$ Square & Adjusted $R$ Square & $\begin{array}{c}\text { Std. Error of the } \\
\text { Estimate }\end{array}$ \\
\hline 1 & $0,765^{\mathrm{a}}$ & 0,585 & 0,548 & 2,129 \\
\hline
\end{tabular}

Sumber: Data Penelitian, 2021 
Berdasarkan Tabel 3, besarnya pengaruh variabel bebas terhadap variabel terikat yang ditunjukkan oleh nilai determinasi total (Adjused $R$ Square) sebesar 0,548 mempunyai arti bahwa sebesar $54,8 \%$ variasi kinerja keuangan dipengaruhi oleh variasi risiko kredit, risiko likuiditas, risiko operasional, dewan komisaris dan dewan direksi, sedangkan sisanya sebesar $45,2 \%$ dijelaskan oleh faktor lain yang tidak dimasukkan ke dalam model. Uji F digunakan untuk mengetahui pengaruh variabel bebas secara bersama-sama terhadap variabel terikat. Uji $\mathrm{F}$ dilakukan dengan melihat nilai signifikan pada tabel Anova, signifikan berarti hubungan yang terjadi dapat berlaku untuk populasi. Jika tingkat signifikan $\mathrm{F}<0,05$ maka $\mathrm{H}_{0}$ ditolak, sedangkan jika tingkat signifikan $\mathrm{F} \geq 0,05$ maka $\mathrm{H}_{0}$ diterima (Ghozali, 2016).

Tabel 4. Hasil Uji Kelayakan Model

\begin{tabular}{llccccc}
\hline Model & & Sum of Squares & Df & Mean Square & $F$ & Sig. \\
\hline 1 & Regression & 357,533 & 5 & 71,507 & 15,769 & $0,000^{\mathrm{b}}$ \\
& Residual & 253,937 & 56 & 4,535 & & \\
& Total & 611,470 & 61 & & & \\
\hline
\end{tabular}

Sumber: Data Penelitian, 2021

Berdasarkan Tabel 4, hasil uji signifikansi simultan (Uji F) diperoleh nilai signifikansi F sebesar 0,000. Nilai Signifikansi 0,000<0,05 mengindikasikan bahwa variasi risiko kredit, risiko likuiditas, risiko operasional, dewan komisaris dan dewan direksi secara simultan berpengaruh signifikan terhadap kinerja keuangan sehingga model layak digunakan untuk memprediksi. Uji statistik $\mathrm{t}$ digunakan untuk menguji pengaruh variabel bebas pada variabel terikatnya. Taraf nyata atau level of significant (a) yang digunakan adalah 5 persen $(0,05)$.

Tabel 5. Hasil Uji t

\begin{tabular}{|c|c|c|c|c|c|}
\hline \multirow[t]{2}{*}{ Model } & \multicolumn{2}{|c|}{$\begin{array}{c}\text { Unstandardized } \\
\text { Coefficients }\end{array}$} & \multirow{2}{*}{$\begin{array}{c}\text { Standardized } \\
\text { Coefficients }\end{array}$} & \multirow[t]{2}{*}{$\mathrm{t}$} & \multirow[t]{2}{*}{ Sig. } \\
\hline & $\mathrm{B}$ & Std. Error & & & \\
\hline 1 (Constant) & 17,927 & 10,157 & & 1,765 & 0,000 \\
\hline Risiko Kredit & $-0,007$ & 0,037 & $-0,019$ & $-3,194$ & 0,000 \\
\hline Risiko Likuiditas & $-0,007$ & 0,032 & $-0,019$ & $-4,205$ & 0,000 \\
\hline Risiko Operasional & $-0,167$ & 0,021 & $-0,777$ & $-7,801$ & 0,000 \\
\hline Dewan Komisaris & 0,582 & 4,382 & 0,012 & 5,133 & 0,000 \\
\hline Dewan Direksi & 0,861 & 2,165 & 0,035 & 3,398 & 0,000 \\
\hline
\end{tabular}

a. Dependent Variable: Kinerja Keuangan

Sumber: Data Penelitian, 2021

Berdasarkan hasil uji t risiko kredit terhadap kinerja keuangan diperoleh nilai signifikansi sebesar 0,000 dengan nilai koefisien beta -0,007. Nilai Signifikansi $0,000<0,05$ mengindikasikan bahwa $\mathrm{H}_{1}$ diterima. Hasil ini mempunyai arti risiko kredit berpengaruh negatif pada kinerja keuangan BPR di Kabupaten Badung. Dengan kata lain semakin meningkat risiko kredit maka kinerja keuangan akan semakin menurun, sebaliknya jika risiko kredit semakin menurun, maka kinerja keuangan akan semakin meningkat.

Risiko kredit merupakan risiko yang terjadi akibat ketidakmampuan suatu perusahaan dalam memenuhi kewajibannya tepat pada waktu yang telah disepakati. Keputusan investasi dalam hal ini memiliki keterkaitan kuat, karena investor akan mengalirkan dana mereka kepada suatu lembaga atau pihak yang memiliki sistem keamanan dan menguntungkan. Perbankan mendapat aliran 
dana dari investor dengan tanggungjawab dalam memberikan sejumlah keuntungan dalam bentuk bunga dan mengelola dana tersebut dalam bentuk kredit, serta mengambil selisih keuntungan sebagai pendapatan perbankan. Maka, jika hal ini membuat para investor merasakan adanya permasalahan yang membuat ketidaknyamanan pada saat dana itu ditempatkan, salah satunya disebabkan oleh masalah kredit yang mengakibatkan perusahaan memiliki risiko kredit tinggi.

Risiko kredit dapat diukur menggunakan Non Performing Loan (NPL). NPL merupakan perbandingan antara total kredit bermasalah dengan total kedit yang diberikan kepada debitur, semakin kecil NPL maka bank dapat mengelola risiko kreditnya dengan baik sehingga dapat berdampak baik pada penilaian kinerja keuangan bank. Hal ini sesuai juga dengan teori sinyal (signalling theory) dimana sinyal yang baik akan berpengaruh baik terhadap pasar. Nilai NPL yang rendah mencerminkan sinyal yang baik sehingga dapat berpengaruh meningkatkan rating bank.

Hasil penelitian sebelumnya Fitri, (2016) memperoleh hasil penerapan risiko kredit (NPL) berpengaruh negatif signifikan terhadap kinerja keuangan. (Bastomi et al., 2017) menyatakan bahwa risiko kredit berpengaruh negatif terhadap kinerja keuangan.

Berdasarkan hasil uji $\mathrm{t}$ risiko ikuiditas terhadap kinerja keuangan diperoleh nilai signifikansi sebesar 0,000 dengan nilai koefisien beta -0,007. Nilai Signifikansi 0,000 $<0,05$ mengindikasikan bahwa $\mathrm{H}_{2}$ diterima. Hasil ini mempunyai arti bahwa risiko likuiditas berpengaruh negatif pada kinerja keuangan BPR di Kabupaten Badung. Dengan kata lain semakin menurun risiko likuiditas akan semakin meningkatkan kinerja keuangan, sebaliknya jika risiko likuiditas semakin meningkat maka kinerja keuangan akan semakin menurun.

Risiko likuiditas (liquidity risk) adalah risiko yang dapat dihadapi bank untuk memenuhi kebutuhan likuiditas mereka dan untuk merespons secara bersamaan dengan aplikasi pinjaman dan semua penarikan tunai yang dilakukan oleh penabung. Risiko likuiditas muncul ketika bank tidak dapat menyediakan likuiditas untuk memenuhi kebutuhan perdagangan pelanggan dan untuk memenuhi kewajibannya yang harus dipenuhi dalam waktu kurang dari satu tahun.

LDR adalah rasio dari jumlah total pinjaman bank terhadap dana yang diterima dari bank (Anam \& Handayani, 2018). Semakin tinggi LDR, semakin tinggi dana yang ditransfer ke dana pihak ketiga. Dengan penyaluran dana pihak ketiga yang besar maka bank akan memperoleh kinerja (ROA) yang semakin meningkat. Karena semakin besar utang bank maka semakin menurun kinerja keuangan bank. Hal ini juga sesuai dengan teori sinyal (Signalling Theory) yang menyatakan bahwa sinyal yang baik akan berpengaruh baik terhadap pasar. LDR yang tinggi mencerminkan sinyal yang baik karena menggambarkan tingkat likuiditas yang bagus, sehingga dapat meningkatkan rating bank.

Hasil penelitian sebelumnya Sandy (2015) dan Wibowo, (2020) memperoleh hasil LDR berpengaruh negatif terhadap kinerja keuangan perbankan.

Berdasarkan hasil uji t risiko operasional terhadap kinerja keuangan diperoleh nilai signifikansi sebesar 0,000 dengan nilai koefisien beta -0,167. Nilai Signifikansi 0,000<0,05 mengindikasikan bahwa $\mathrm{H}_{3}$ diterima. Hasil ini mempunyai 
arti bahwa risiko operasional berpengaruh negatif pada kinerja keuangan BPR di Kabupaten Badung. Dengan kata lain semakin meningkat risiko operasional maka kinerja keuangan semakin menurun, sebaliknya jika risiko operasional semakin menurun maka kinerja keuangan akan semakin meningkat. Risiko operasional dalam penelitian ini diproksikan pada risiko operasional dalam BPR yang diukur menggunakan BOPO. Seperti yang diungkapkan dalam teori sinyal (signalling theory) bahwa sinyal yang baik akan memberikan pengaruh yang baik juga terhadap pasar. Dalam hal ini BOPO yang rendah mencerminkan sinyal yang baik sehingga dapat berpengaruh baik terhadap pasar yang digambarkan oleh rating bank.

Hasil penelitian sebelumnya Wirawan \& Putri (2018) memperoleh hasil Risiko operasional berpengaruh negatif pada kinerja keuangan koperasi di Kabupaten Gianyar. Ismanto (2020)memperoleh hasil risiko operasional berpengaruh negatif pada kinerja keuangan. Berdasarkan hasil uji $t$ dewan komisaris terhadap kinerja keuangan diperoleh nilai signifikansi sebesar 0,000 dengan nilai koefisien beta 0,582. Nilai Signifikansi 0,000 <0,05 mengindikasikan bahwa $\mathrm{H}_{4}$ diterima. Hasil ini mempunyai arti bahwa dewan komisaris berpengaruh positif pada kinerja keuangan BPR di Kabupaten Badung. Dengan kata lain dewan komisaris berpengaruh terhadap peningkatan atau penurunan kinerja keuangan.

Berdasarkan teori keagenan merupakan dasar yang digunakan untuk memahami corporate governance. Teori keagenan mengakibatkan hubungan yang asimetri antara pemilik dan pengelola, untuk menghindari terjadi hubungan yang asimetris tersebut dibutuhkan suatu konsep good corporate governance yang bertujuan untuk menjadikan perusahaan menjadi sehat. Dewan komisaris memiliki andil yang sangat besar dalam pelaksanaan GCG. Jika fungsi dewan komisaris sudah berjalan efektif maka system pengawasan di perusahaan tersebut semakin baik serta dapat menjamin kesuksesan pelaksanaan GCG, dan pada akhirnya akan berdampak positif pada kinerja keuangan. Teori agensi menyatakan dewan komisaris merupakan mekanisme pengendalian intern tertinggi yang bertanggung jawab untuk memonitor segala tindakan manajer dalam mengelola perusahaan.

Hasil penelitian sebelumnya Sulistyowati \& Fidiana (2017) memperoleh hasil ukuran dewan komisaris yang dilihat dari jumlah dewan komisaris berpengaruh positif pada kinerjaa keuangan. Berdasarkan hasil uji t dewan direksi terhadap kinerja keuangan diperoleh nilai signifikansi sebesar 0,000 dengan nilai koefisien beta 0,861 . Nilai Signifikansi $0,000<0,05$ mengindikasikan bahwa mengindikasikan bahwa $\mathrm{H}_{5}$ diterima. Hasil ini mempunyai arti bahwa dewan direksi berpengaruh positif pada kinerja keuangan BPR di Kabupaten Badung. Dengan kata lain dewan direksi berpengaruh terhadap peningkatan atau penurunan kinerja keuangan.

Berdasarkan teori keagenan yang menjelaskan bahwa adanya konflik kepentingan anatara manajemen (agent) dan pemilik (principal). Pemilik ingin mengetahui semua informasi yang ada di perusahaan termasuk aktivitas manajemen dan sesuatu yang terkait investasi atau dananya dalam perusahaan. Hal ini dilakukan agar manajer bekerja sesuai dengan strategi yang telah ditentukan sebelumnya oleh perusahaan. Setiap perusahaan pasti memiliki dewan 
direksi yang bertugas untuk melakukan pengurusan perusahaan sesuai maksud dan tujuan perusahaan yang telah diatur dalam anggaran dasar perusahaan. Dewan direksi dalam suatu perusahaan akan menentukan kebijakan yang akan diambil atau strategi perusahaan secara jangka pendek maupun jangka panjang, maka semakin besar kebutuhan akan hubungan eksternal yang semakin efektif, maka kebutuhan akan dewan dalam jumlah yang besar akan semakin tinggi (Semani, 2008).

Deskripsi bahwa manajer adalah agen bagi para pemegang saham atau dewan direksi adalah benar sesuai dengan teori keagenan. Dewan direksi merupakan pihak dalam suatu entitas perusahaan yang bertugas melakukan dan melaksanakan operasi dan kepengurusan perusahaan. Dewan direksi bertanggung jawab penuh atas segala bentuk operasional dan kepengurusan perusahaan dalam rangka melaksanakan kepentingan-kepentingan dalam pencapaian tujuan perusahaan. Direksi pada dasarnya memiliki hak pengendalian yang siginifikan dalam pengelolaan sumber daya perusahaan dan dana dari investor (Sukandar, 2014). Semakin meningkatnya jumlah dewan direksi, maka akan semakin banyak yang melakukan pengawasan terhadap pengelolaan sumber daya perusahaan.

Hasil penelitian sebelumnya Meirina \& Abaharis (2019) memperoleh hasil dewan direksi berpengaruh positif dan signifikan pada kinerja keuangan perbankan. Laksana (2015) memperoleh hasil semakin besar jumlah dewan direksi dalam perusahaan maka koordinasi dan komunikasi akan cenderung lebih mudah dilakukan, sehingga kinerja keuangan perusahaan akan semakin meningkat.

\section{SIMPULAN}

Berdasarkan hasil pemaparan di atas diperoleh bahwa risiko kredit berpengaruh negatif terhadap kinerja keuangan. Hal tersebut mengimplikasikan bahwa untuk memperoleh kinerja keuangan yang maksimal maka pihak manajemen hendaknya meminimalkan risiko kredit. Risiko kredit merupakan risiko yang terjadi akibat ketidakmampuan suatu perusahaan dalam memenuhi kewajibannya tepat pada waktu yang telah disepakati. Dengan demikian maka risiko kredit dapat dinimalisir dengan cara meminimalkan Non Performing Loan (NPL). Selain itu, pemaparan diatas menunjukan bahwa risiko likuiditas berpengaruh negatif terhadap kinerja keuangan. Hal tersebut mengimplikasikan bahwa untuk meningkatkan kinerja keuangan maka pihak manajemen perusahaan harus meminimalkan risiko likuiditas. Risiko likuiditas (liquidity risk) adalah risiko yang dapat dihadapi bank untuk memenuhi kebutuhan likuiditas mereka dan untuk merespons secara bersamaan dengan aplikasi pinjaman dan semua penarikan tunai yang dilakukan oleh penabung. Dengan demikian kinerja keuangan dapat dimaksimalkan dengan meminimalkan risiko likuiditas. Risiko operasional berpengaruh negatif terhadap kinerja keuangan. Hal tersebut mengimplikasikan bahwa untuk meningkatkan kinerja keuangan maka pihak manajemen perusahaan harus meminimalkan risiko operasional. Risiko dalam penelitian ini diproksikan pada risiko operasional dalam BPR yang diukur menggunakan BOPO. Dengan demikian kinerja keuangan dapat dimaksimalkan dengan meminimalkan risiko operasional. Dewan komisaris dan Dewan direksi 
berpengaruh positif terhadap kinerja keuangan. Hal tersebut mengimplikasikan bahwa ukuran dewan komisaris dan dewan direksi mempengaruhi kinerja keuangan, semakin meningkatnya jumlah dewan komisaris dan dewan direksi maka akan semakin banyak yang melakukan pengawasan terhadap pengelolaan sumber daya perusahaan.

Berdasarkan penelitian yang telah dilakukan maka terdapat beberapa keterbatasan dalam penelitian ini. Hal tersebut berupa terbatasnya periode tahun yang digunakan yaitu hanya pada tahun 2018 - 2019. Hal tersebut hendaknya diatasi dengan cara menambah periode laporan keuangan yang digunakan. Sedangkan variabel yang digunakan dalam mengkontruksi model penelitian hanya terdiri dari lima variabel independent. Hal tersebut kedepannya hendaknya dapat diatasi dengan cara merekontruksi ulang model penelitian lain dengan mengkombinasikan dengan variabel lain baik dalam bentuk mediasi maupun moderasi. Bagi Peneliti selanjutnya yang ingin meneliti lebih lanjut pengaruh risiko kredit, risiko likuiditas, risiko operasional, dewan komisaris dan dewan direksi terhadap kinerja keuangan pada BPR di Kabupaten Badung dapat dilakukan dengan menambah sampel perusahaan serta menambah data berdasarkan tahun guna mendapatkan hasil yang sesuai dengan kenyataan sebenarnya.

\section{REFERENSI}

Agustini, N. L. P., Wiagustini, N. L. P., \& Purbawangsa, I. B. A. (2017). Pengaruh Kecukupan Modal Dan Risiko Kredit Terhadap Profitabilitas: Likuiditas Sebagai Pemediasi Pada Bank Perkreditan Rakyat di Kabupaten Badung. E-Jurnal Ekonomi Dan Bisnis Universitas Udayana, 6, 2161-2192. https:// doi.org/ISSN : 2337-3067

Ariestya, P., \& Ardiana, P. (2016). Implementasi Good Corporate Governance Pada Kinerja Perusahaan Sektor Keuangan Dengan Manajemen Risiko Sebagai Variabel Intervening. E-Jurnal Akuntansi, 16(2), 1461-1488.

Bastomi, M., Salim, U., \& Aisjah, S. (2017). The Role of Corporate Governance and Risk Management on Banking Financial Performance in Indonesia. Jurnal Keuangan Dan Perbankan, 21(4), 589-599. https:// doi.org/10.26905/jkdp.v21i4.1285

Cahyaningtyas, S. R., \& Sasanti, E. E. (2019). Penerapan Manajemen Resiko Bank, Tata Kelola Perusahaan Dan Kinerja Perusahaan Perbankan Indonesia. 3, 170-206.

Erawati, C., \& Teguh, J. (2020). Pengaruh Risiko Kredit, Likuiditas, Profitabilitas Pada Kinerja Keuangan Perbankan Yang Terdaftar Di Bei. Jurnal Riset Manajemen Dan Bisnis, 15.

Fitri, aulia diani. (2016). Pengaruh Risiko Pasar, Risiko Kredit Dan Risiko Operasional Terhadap Kinerja Keuangan Perbankan. Ejournal.Unp.Ac.Id, 4, 37-39.

Ghozali, I. (2016). Aplikasi Analisis Multivariate dengan Program IBM SPSS 21 :Update PLS Regresi. Semarang. https:/ / doi.org/10.2307/1579941

Hart, O. (1995). Corporate Governance: Some Theory and Implications. The Economic Journal. https:// doi.org/10.2307/2235027 
Ismanto, D. (2020). Pengaruh Penerapan Manajemen Risiko Terhadap Kinerja Keuangan Sektor Perbankan Periode 2013-2017. JURNAL FOKUS, 10(1), 102-120.

Jensen, M. C., \& Meckling, W. H. (1976). Theory of the firm: Managerial behavior, agency costs and ownership structure. Journal of Financial Economics. https:// doi.org/10.1016/0304-405X(76)90026-X

Korompis, R. R. N., Murni, S., Untu, V. N. B. (2020). Pengaruh Risiko Pasar (Nim), Risiko Kredit (Npl), Dan Risiko Likuiditas (Ldr) Terhadap Kinerja Keuangan Perbankan (Roa) Pada Bank Yang Terdaftar Di Lq 45 Periode 2012-2018. Jurnal EMBA: Jurnal Riset Ekonomi, Manajemen, Bisnis Dan Akuntansi, 8(1), 175-184. https:// doi.org/10.35794/emba.v8i1.27499

Lukas, S., \& Basuki, B. (2015). the Implementation of Good Corporate. The International Journal of Accounting and Business Society.

Meirina, E., \& Abaharis, H. (2019). Mekanisme Good Corporate Governance dan Leverage Terhadap Kinerja Keuangan Perbankan. 03(03), 215-226. https:// doi.org/10.31575/jp.v3i3.195

Nurintan, Y. (2016). Pengaruh penerapan manajemen risiko kredit, risiko pasar, risiko likuiditas dan risiko operasional terhadap kinerja keuangan perbankan (Studi pada Bank Umum Konvensional Go Public Periode 20112015). Skripsi.

Sugiyono. (2017). MetodePenelitian Kuantitatif, Kualitatif dan R\&D. Bandung: PT Alfabet. Sugiyono. (2017). MetodePenelitian Kuantitatif, Kualitatif Dan RED. Bandung: PT Alfabet. https://doi.org/10.1017/CBO9781107415324.004

Wibowo, I. A. A., Wiyono, G., \& Rinofah, R. (2020). Pengaruh Risiko Likuiditas , Net Interest Margin, Dan Good Corporate Governance Terhadap Kinerja. MODUS Journals, 32(1), 53-65.

Wirawan, A. . G. B. P., \& Dwija Putri, I. G. A. M. A. (2018). Pengaruh Penerapan Prinsip-Prinsip Good Corporate Governance dan Manajemen Risiko Pada Kinerja Keuangan Koperasi di Kabupaten Gianyar. E-Jurnal Akuntansi, 23, 1791. https:// doi.org/10.24843/eja.2018.v23.i03.p07 